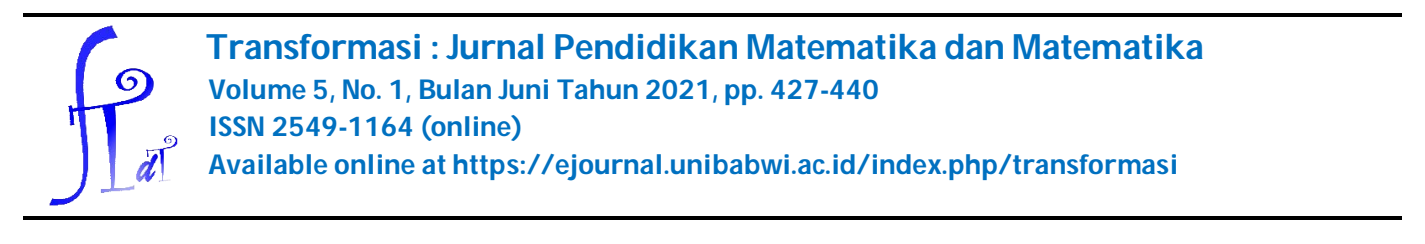

\title{
KECEMASAN SISWA TERHADAP MATEMATIKA PADA PEMBELAJARAN ONLINE DI MASA PANDEMI COVID-19 DITINJAU DARI TINGKATAN SEKOLAH DAN GENDER
}

\author{
Luthfiyah $^{1}$, Windia Hadi ${ }^{2}$ \\ ${ }^{1,2}$ Pendidikan Matematika, FKIP, Universitas Muhammadiyah Prof. DR. HAMKA \\ email korespondensi : windia.hadi@ uhamka.ac.id
}

Diterima : (21-01-2021), Revisi: (08-03-2021), Diterbitkan : (07-05-2021)

\begin{abstract}
ABSTRAK
Kecemasan matematika merupakan kondisi mental siswa dalam kegiatan proses belajar matematika. Studi ini menganalisis kecemasan siswa terhadap matematika dalam pembelajaran online di masa pandemi covid-19. Penelitian ini menggunakan metode survei dengan 15 pernyataan kuesioner. Sampel penelitian adalah 323 siswa terdiri dari 153 siswa SMP dan 170 siswa SMA yang merupakan perwakilan siswa di Indonesia. Analisis data yang digunakan adalah menggunakan Winsteps. Hasil analisis penelitian ini menunjukkan bahwa kecemasan siswa belajar matematika dalam pembelajaran online terbagi menjadi kecemasan tinggi, kecemasan sedang, dan kecemasan rendah. Siswa SMP memiliki tingkat kecemasan belajar tinggi sebesar 3,92\% dan Siswa SMA memiliki tingkat kecemasan belajar tinggi sebesar 1,17\%. Hal ini menunjukkan bahwa kecemasan belajar matematika lebih banyak dialami oleh siswa SMP daripada siswa SMA, khususnya pada Kelas 7 dan 8. Sedangkan berdasarkan gender, siswa Laki-laki memiliki kecemasan tinggi sebesar 4\%, dan siswa perempuan $1,8 \%$. Siswa yang memiliki kecemasan tinggi lebih cenderung tidak menyukai matematika dan menganggap matematika pelajaran yang sulit.
\end{abstract}

Kata kunci : Covid-19, Kecemasan Belajar, Matematika, Pembelajaran Online 


\begin{abstract}
Mathematical anxiety is a student's mental condition in the learning process of mathematics. This study analyzes students' anxiety about mathematics in online learning during the Covid-19 pandemic. This study used a survey method by providing 15 questionnaire statements. The sample of this study was 323 students among 153 junior high school students and 170 high school students from various student representatives in Indonesia. The data analysis used was Winsteps. The results of the analysis of this study indicate that the anxiety of students learning mathematics in online learning is divided into high anxiety, moderate anxiety, and low anxiety. First Middle School (SMP) has a high level of learning anxiety towards mathematics of 3.92\% and Senior High School has a high anxiety level of $1.17 \%$. This shows that junior high school has more anxiety towards learning mathematics, especially in grade 7 and grade 8 . Meanwhile, based on gender, males have high anxiety by $4 \%$ than females, namely $1.8 \%$. Students who have high anxiety are more likely to dislike math and find mathematics a difficult subject.
\end{abstract}

Key words: Covid-19, Learning Anxiety, Mathematics, Online Learning

\title{
Pendahuluan
}

Pada akhir tahun 2019 dunia mulai dilanda wabah Covid-19 (Corona Virus Disease). Virus ini pertama kali muncul di Wuhan, China yang kemudian menyebar kebeberapa belahan dunia termasuk Indonesia. Covid-19 muncul di Indonesia pada bulan 2 Maret 2020 dengan kasus awal 2 orang warga Jakarta yang terindikasi positif Covid-19 sepulang dari negara Jepang. Kurangnya persiapan di Indonesia menghadapi Covid-19 membuat angka penyebaran Covid-19 di Indonesia naik sangat pesat. Hingga pada akhirnya pemerintah menerapkan PSBB (Pembatasan Sosial Berskala Besar) di berbagai daerah. Dengan adanya PSBB ini banyak dari berbagai bidang harus ditutup sementara dan diarahkan menjadi WFH (Work From Home). Salah satu bidang yang harus ditutup adalah bidang pendidikan. Artinya tidak ada pembelajaran secara tatap muka di Sekolah dan beralih ke proses daring (dalam jaringan) atau online.

Di Indonesia, Pemerintah telah membatasi mobilisasi komunitas dalam upaya untuk mencegah penyebaran penyakit dan terus mempromosikan agenda bekerja dari rumah, belajar dari rumah dan beribadah di rumah. Sekolah dan Institusi Pendidikan Tinggi di Indonesia sudah ditutup sementara sejak 14 Maret 2020 (Mailizar et al., 2020). Pelaksanaan pembelajaran dengan e-learning juga digaungkan oleh Nadiem Makarim (selaku Menteri Pendidikan dan Kebudayaan) sebagai 
pembelajaran mandiri. Untuk itu, Siswa dituntut melek teknologi, kreatif, tinggi motivasi, mampu melakukan inovasi yang tujuannya mempersiapkan masa depan milineal harus siap dengan tantangan globalisasi (Zaharah et al., 2020).

Dalam satu dekade terakhir, teknologi informasi dan internet telah mengalami perkembangan yang sangat pesat memungkinkan metode pembelajaran untuk mengalami inovasi seperti e-learning (Azis et al., 2019). Pembelajaran jarak jauh telah menjadi fenomena yang menyebar dan berkembang sehingga memberikan dorongan yang luar biasa untuk penggunaan teknologi informasi dan komunikasi di perguruan tinggi (Markova et al., 2017). Pembelajaran mandiri di era digital juga merupakan fenomena yang berkembang dengan implikasi untuk proses pembelajaran dan atribut pelajar (Curran et al., 2019). Siswa pendidikan jarak jauh harus memiliki keterampilan Self-regulated learning (SRL), yang merupakan bagian dari mengelola, mengatur, dan memantau proses belajar sehingga mereka dapat mencapai tujuan belajarnya (Rahayu et al., 2017).

Namun, para penentang mengungkapkan kekhawatiran bahwa siswa di lingkungan online cenderung merasa lebih bingung, terisolasi, dan frustrasi, dan sebagai akibatnya efektivitas dan kepuasan belajar mereka dapat berkurang (Damary et al., 2017). Pencapaian suatu tujuan belajar bukanlah suatu hal yang mudah dan tidak akan selalu dapat berjalan dengan baik karena dalam penyelenggaraannya akan terdapat faktor-faktor yang mempengaruhi. Banyak faktor yang mempengaruhi ketercapaian tujuan pendidikan, diantaranya adalah faktor intrinsik maupun faktor ekstrinsik. Salah satu faktor yang berasal dari intrinsik adalah kesiapan belajar dan kecemasan matematika (Himmi \& Azni, 2017).

Kecemasan adalah respon total manusia terhadap ancaman atau bahaya. Setiap pengalaman kecemasan melibatkan persepsi bahaya, pemikiran tentang bahaya, dan proses alarm fisiologis dan aktivasi (Moss, 2002). Kecemasan matematis merupakan suatu perasaan tidak nyaman yang muncul akibat dari emosi yang tidak stabil yang ditandai dengan rasa khawatir, tegang, takut, dan was-was ketika mengahadapi suatu kegiatan yang tidak dikehendakinya dalam pembelajaran matematika (Wahyudy, 2019). Kecemasan matematika adalah salah satu faktor emosional yang dapat sangat mengganggu beberapa anak dan orang dewasa yang belajar dan berprestasi dalam matematika (Dowker et al., 2016). Kecemasan matematika dapat terjadi karena banyak alasan (Mutlu, 2019). 
Kecemasan matematika terbagi menjadi tiga kelompok, yaitu situasional, situasi pribadi, dan kepribadian. Faktor-faktor seperti umur, jenis kelamin, dan status sosial ekonomi disebutkan sebagai alasan pribadi untuk kecemasan (Aydın \& Aytekin, 2019). Siswa perempuan memiliki kecemasan lebih tinggi daripada siswa laki-laki (Hill et al., 2016). Siswa perempuan cenderung memiliki kecemasan matematika dibandingkan siswa laki-laki, karena lebih banyak waktu yang dihabiskan untuk membereskan pekerjaan rumah (Cheema \& Sheridan, 2015).

Hambatan pembelajaran online dapat diklasifikasikan berdasarkan empat bidang yang mempengaruhinya, yaitu : pelajar, guru, kurikulum dan sekolah (Assareh \& Bidokht, 2011). Penelitian lain menunjukkan bahwa, teknologi digital dikembangkan untuk mendukung pembelajaran mandiri siswa (Curran et al., 2019). Selain itu diketahui juga bahwa kecemasan belajar dan kesulitan belajar pada pelajaran matematika mempengaruhi hasil belajar siswa (Ulfiani et al., 2015).

Berdasarkan uraian diatas, peneliti ingin mengetahui kecemasan siswa terhadap matematika dalam pembelajaran jarak jauh di masa pandemi Covid-19 ditinjau dari tingkatan sekolah dan gender. Serta mengetahui kelebihan dan kekurangan dalam proses pembelajaran jarak jauh.

\section{Metode Penelitian}

Penelitian ini menggunakan metode survei untuk pengumpulan data. Instrumen terdiri dari 15 pernyataan (Tabel 1). Subjek penelitian ini adalah 153 siswa SMP dan 170 siswa SMA dari Sekolah-Sekolah yang tersebar di daerah DKI Jakarta, Jawa Barat, Banten, Jawa Tengah, Jawa Timur, Sumatra, dan Kalimantan. Penelitian ini melalui beberapa proses atau tahapan sebelum dilakukan analisis hasil angket kecemasan belajar matematika. Langkah pertama yang dilakukan peneliti adalah validasi angket kecemasan belajar matematika di masa pandemi covid-19. Proses validasi dilakukan oleh dua dosen. Kedua validator menyatakan bahwa angket sesuai untuk digunakan dengan beberapa revisi terkait bahasa. Tahap kedua adalah membuat angket dengan Google Form. Tahap ketiga adalah analisis data. Proses analisis dilakukan dengan menggunakan tabel variabel peta WinSteps. Gambar 1. menunjukkan bagan alur penelitian. 


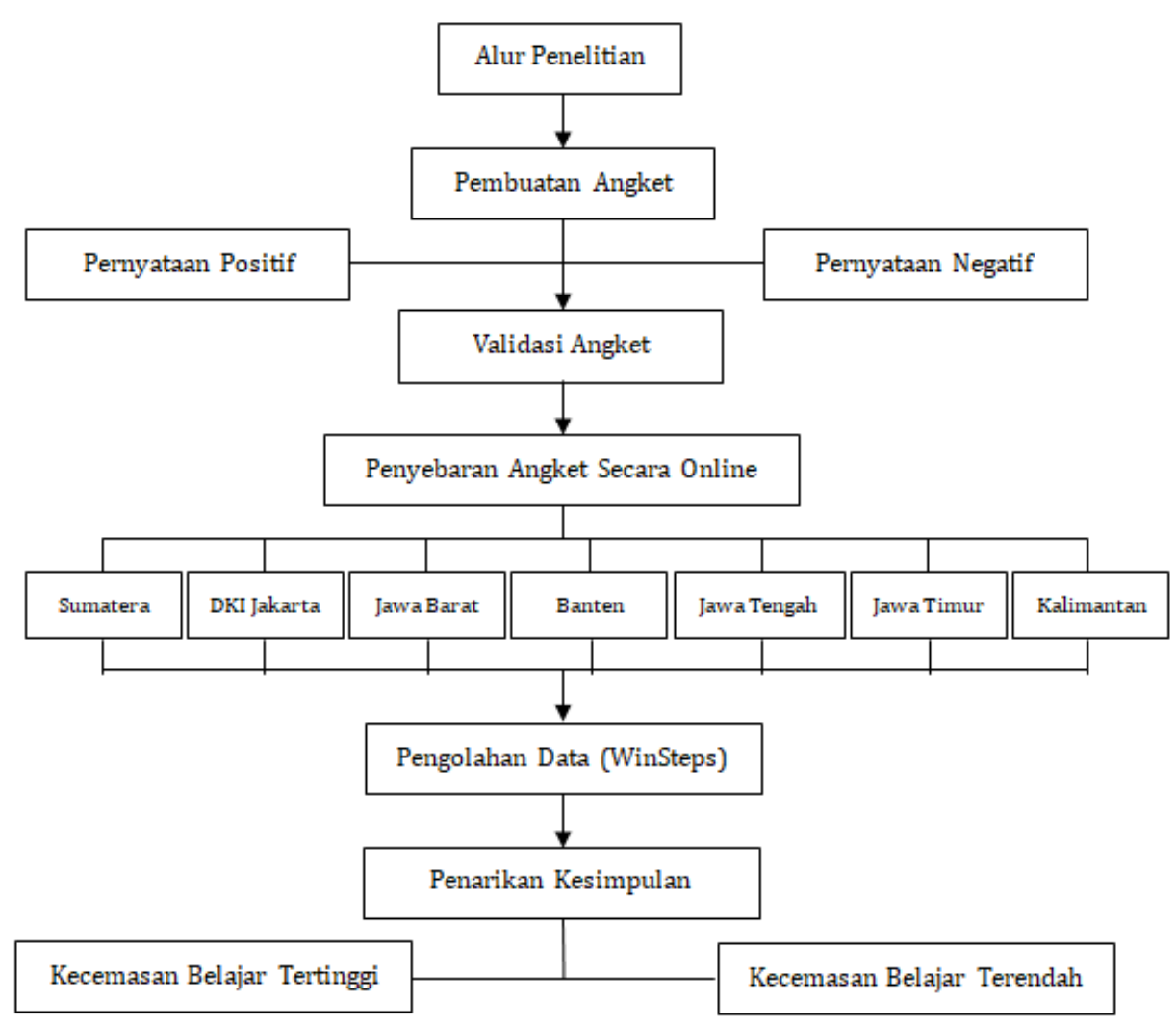

Gambar 1. Bagan Alur Penelitian

Instrumen yang digunakan dalam penelitian ini adalah angket untuk mengetahui kecemasan yang dialami siswa selama belajar matematika dengan pembelajaran jarak jauh. Ada empat indikator dalam instrumen kecemasan matematika yaitu kecemasan pada pembelajaran online, kecemasan memahami matematika, kecemasan pada akses media, dan kecemasan terhadap orang lain. Untuk mengetahui rasa yang dialami siswa tersebut peneliti memberikan 15 pernyataan. Terdapat empat item pilihan jawaban pada survei dengan yaitu : "Sangat Setuju (SS)", "Setuju (S)”, "Tidak Setuju (TS)”, serta "Sangat Tidak Setuju (STS)" (Cheema \& Sheridan, 2015). Angket dibagikan secara online dengan menyebarkan tautan yang dapat diakses siswa. Untuk memudahkan pengumpulan data, peneliti memanfaatkan aplikasi Google Form (Tiara, 2016). 
Tabel 1. Indikator Instrumen Survei Kecemasan Matematika

\begin{tabular}{cl}
\hline No & \\
\hline P1 & Saya saat ini belajar matematika secara online di masa pandemi Covid-19 \\
P2 & Saya merasa senang belajar matematika secara online di masa pandemi Co- \\
& vid-19 \\
P3 & Saya merasa cemas, karena tugas yang diberikan guru saat pembelajaran \\
& online lebih banyak daripada saat pembelajaran tatap muka \\
P7 & Saya merasa cemas apabila nilai harian belajar online saya lebih jelek dari \\
& sebelumnya \\
P10 & Saya merasa lebih efektif belajar matematika secara online di masa pandemi \\
& Covid-19
\end{tabular}

Kecemasan Memahami Matematika

P6 Banyak materi/soal pelajaran matematika yang tidak saya pahami ketika pembelajaran online

P13 Karena sedang masa pandemi Covid-19, saya menjadi lebih mandiri dalam belajar matematika

\begin{tabular}{cl}
\hline Kecemasan Pada Akses Media \\
P4 & Adanya aplikasi online lainnya yang dilakukan guru selain memberikan \\
& materi/ soal pelajaran matematika lewat media WhatsApp \\
P11 & Saya kesulitan mengakses media online yang ditentukan dari Sekolah, karena \\
& terkendala jaringan dan kuota internet \\
P14 & Daripada saya harus pusing mencari materi matematika tambahan di Google \\
& lebih baik saya memakai jasa privat untuk membantu saya \\
\hline
\end{tabular}

Kecemasan Terhadap Orang Lain

P8 Karena di masa pandemi ini orang tua saya WFH (WorkFromHome), saya jadi bisa bertanya mengenai materi/ soal pelajaran matematika dengan orang tua

P9 Saya kesulitan berdiskusi dengan teman sekelas saya, hanya dengan media online

P15 Saya merindukan masa belajar secara tatap muka

Model Rasch memungkinkan pengubahan data ordinal menjadi data interval. Beberapa keunggulan dalam model Rasch diantaranya adalah mampu memprediksi data yang bias, pengukuran dengan menggunakan skala logit, mengetahui distribusi siswa, mengubah data ordinal menjadi data interval dan menunjukkan peta variabel wright (Ölmez \& Ölmez, 2019). Serta dapat menentukan validasi dan reabilitas angket kecemasan belajar matematika dengan menggunakan perangkat lunak 
WinSteps. Penelitian ini mengkategorikan data demografi subjek ke dalam tingkatan Sekolah, kelas, jenis kelamin dan provinsi.

Tabel 2. Reabilitas Dalam Analisis Rasch Model

\begin{tabular}{ccc}
\hline Statistik & Indeks Fit & Kategori \\
\hline Alpha & $<0,5$ & Buruk \\
Croanbach & $0,5-0,6$ & Jelek \\
(KR-20) & $0,6-0,7$ & Cukup \\
& $0,7-0,8$ & Bagus \\
& $>0.8$ & BagusSekali \\
Reabilitas & $<0,67$ & Lemah \\
Item dan & $0,67-0,80$ & Cukup \\
person & $0,81-0,90$ & Bagus \\
& $0,91-0,94$ & BagusSekali \\
& $>0,94$ & Istimewa \\
Separation & & Nilai pemisahan yang tinggi menunjukkan hal kuali- \\
item dan & & tas instrumennya bagus karena dapat mengidentifi- \\
person & & kasi kelompok item dan responden \\
\hline
\end{tabular}

Untuk membangun reliabilitas dari model Rasch dilakukan dengan tiga kriteria indeks kecocokan yaitu Cronbach's alpha, reabilitas item dan person, serta separation item dan person (Sumintono \& Widhiarso, 2014).

Tabel 3. Ringkasan Statistik Instrumen

\begin{tabular}{crccc}
\hline & Mean & Separation & Reabilitas & Croanbach's $\boldsymbol{\alpha}$ \\
\hline Person & 0,41 & 1,01 & 0,51 & 0,57 \\
Item & 0,09 & 12,55 & 0,99 & \\
\hline
\end{tabular}

Tabel 3 menunjukkan ringkasan statistik Instrumen, Koefisien dari Cronbach's $\alpha$ bernilai 0,57 artinya interaksi antara person dan butir item instrumen secara keseluruhan dalam kategori jelek. Dari nilai Reabilitas person yaitu 0,51 dan reabilitas item dengan skor 0,99 dapat disimpulkan bahwa konsistensi jawaban dari siswa lemah, namun kualitas item dalam instrumen aspek reliabilitasnya istimewa. Sedangkan, skor separation item menunjukkan 12,55 yang artinya makin besar nilai separationnya, maka kualitas instrumen dalam hal keseluruhan responden dan butir item makin bagus, karena bisa mengidentifikasi kelompok responden dan kelompok butir item (Sumintono \& Widhiarso, 2014) 
Tabel 4. Indikator yang Sesuai Untuk Item Fit dan Person Fit

\begin{tabular}{cc}
\hline Statistik & Skor Indikator Fit \\
\hline Outfit Mean Square (MNSQ) & $0,5<\mathrm{MNSQ}<1,5$ \\
Outfit Z-Standard (ZSTD) & $-2,0<$ ZSTD $<+2,0$ \\
Point Measure Correlation (Pt Mean Corr) & $0,4<$ Pt Mean Corr $<0,85$ \\
\hline
\end{tabular}

(Sumintono \& Widhiarso, 2014)

Tabel 4 menunjukkan tiga kriteria yang dapat digunakan untuk menilai item fit, yaitu Outfit Mean Square Values (MNSQ), Outfit Z-Standarized Values (ZSTD), dan Point Mesure Correlation (PTMEA-CORR). Item fit dapat menginformasikan bahwa item tersebut berfungsi normal sesuai dengan ukuran yang diharapkan, sedangkan jika item tersebut menunjukkan misfit maka diindikasikan bahwa responden memiliki miskonsepsi terhadap item tersebut. Tiga kriteria di atas juga dapat digunakan untuk menilai person fit (Sumintono \& Widhiarso, 2014). Sehingga peneliti dapat mengetahui item dan person yang fit atau misfit.

\section{Hasil dan Pembahasan}

Data yang telah dikumpulkan selanjutnya dianalisis menggunakan Winsteps yang bertujuan untuk mengetahui item instrumen yang fit dan misfit, serta mengkategorikan siswa yang memiliki kecemasan belajar matematika tinggi, sedang dan rendah dengan menggunakan tabel peta wright.

Tabel 5. Pernyataan Instrumen yang Misfit (Tidak Sesuai)

\begin{tabular}{ccccc}
\hline Item & Measure & $\begin{array}{c}\text { Outfit MNSQ } \\
\mathbf{( 0 , 5}-\mathbf{~ 1 , 5 )}\end{array}$ & $\begin{array}{c}\text { Outfit ZSTD } \\
\mathbf{( - 2 , 0 - + 2 , 0 )}\end{array}$ & $\begin{array}{c}\text { Pt Mean Corr } \\
\mathbf{( 0 , 4 - 0 , 8 5 )}\end{array}$ \\
\hline P6 & 1,38 & 0,78 & $\mathbf{- 3 , 2 0}$ & 0,60 \\
P7 & 1,13 & 1,22 & $\mathbf{3 , 0 2}$ & 0,39 \\
P3 & 1,05 & 0,95 & $-0,71$ & 0,47 \\
P10 & 0,94 & 0,99 & $-0,17$ & 0,44 \\
P9 & 0,69 & 1,29 & $\mathbf{3 , 9 0}$ & 0,40 \\
P11 & 0,64 & 1,21 & $\mathbf{2 , 8 9}$ & $\mathbf{0 , 3 0}$ \\
P2 & 0,39 & 0,69 & $\mathbf{- 4 , 9 5}$ & 0,51 \\
P14 & 0,04 & 1,03 & 0,47 & $\mathbf{0 , 2 2}$ \\
P12 & $-0,03$ & 1,07 & 1,01 & 0,38 \\
P8 & $-0,15$ & 1,00 & 0,09 & 0,43 \\
P13 & $-0,16$ & 0,75 & $-\mathbf{3 , 8 2}$ & 0,53 \\
P1 & $-0,90$ & 0,90 & $-1,39$ & 0,38
\end{tabular}




\begin{tabular}{ccccc} 
P5 & $-1,06$ & 0,60 & $\mathbf{- 6 , 2 2}$ & 0,43 \\
P4 & $-1,11$ & 0,98 & $-0,22$ & $\mathbf{0 , 1 3}$ \\
P15 & $-2,82$ & $\mathbf{1 , 8 1}$ & $\mathbf{6 , 8 9}$ & $\mathbf{- 0 , 0 2}$ \\
\hline
\end{tabular}

Tabel 5 menunjukkan nilai Outfit MNSQ, Outfit ZSTD, dan PTMEA-CORR untuk misfit item. Angka yang dicetak tebal menunjukkan bahwa item tidak memenuhi kriteria yang disarankan Sumintono \& Widhiarso (2014). Diketahui bahwa item P15 misfit karena tidak memenuhi tiga kriteria yang disarankan, maka item P15 harus diubah. Sementara itu, terdapat lima item (P3, P10, P12, P8, P1) yang memenuhi tiga kriteria yang disarankan, sedangkan 9 item (P6, P7, P9, P11, P2, P14, P13, P5, dan P4) memenuhi setidaknya satu dari tiga kriteria dan harus dipertahankan.

Analisis dalam penelitian ini dilihat dari tiga aspek yaitu kelas, jenis kelamin dan provinsi. Data yang diperoleh dianalisis menggunakan Model Rasch untuk mengetahui tanggapan siswa berdasarkan angket yang dibagikan. Model Rasch menyajikan informasi diagnostik untuk tujuan evaluasi dan perbaikan instrumen (Willse, 2017). Data dikumpulkan dari 323 siswa dari setiap kelas di Sekolah Menengah Pertama dan Sekolah Menengah Atas. Tabel 6 merupakan hasil rangkuman tingkatan kecemasan belajar matematika berdasarkan tingkatan sekolah yaitu SMP dan SMA.

Tabel 6. Jumlah Siswa yang Berdasarkan Tingkatan Kelas

\begin{tabular}{ccccc}
\hline Tingkatan & Kelas & $\begin{array}{c}\text { Kecemasan } \\
\text { Tinggi }\end{array}$ & $\begin{array}{c}\text { Kecemasan } \\
\text { Sedang }\end{array}$ & $\begin{array}{c}\text { Kecemasan } \\
\text { Rendah }\end{array}$ \\
\hline SMP & 7 & 4 & 33 & 0 \\
& 8 & 2 & 55 & 1 \\
& 9 & 0 & 56 & 2 \\
SMA & 10 & 2 & 43 & 0 \\
& 11 & 0 & 61 & 4 \\
& 12 & 0 & 60 & 0 \\
\hline
\end{tabular}

Tabel 6 dan Gambar 2 menunjukkan bahwa tingkatan SMP lebih memiliki kecemasan tinggi dibandingkan dengan siswa SMA, yaitu sebesar 3,92\% untuk tingkat SMP dan 1,17\% untuk tingkat SMA. Hal ini dapat diketahui pada peta variabel maps siswa SMP khususnya kelas 7 (kode A) dan 8 (Kode B) memiliki kecemasan tinggi dibanding siswa kelas 9 (Kode C). Kecemasan siswa kelas 7 sebesar 2,61\%, siswa kelas 8 sebesar 1,30\%, dan siswa kelas 9 sebesar 0\%. Sedangkan, siswa SMA kelas 10 (Kode D) memiliki kecemasan tinggi dibandingkan kelas 11 (Kode E) dan 
12 (Kode F). Kecemasan siswa kelas 10 sebesar 1,17\%, siswa kelas 11 sebesar 0\%, dan siswa kelas 12 sebesar $0 \%$.

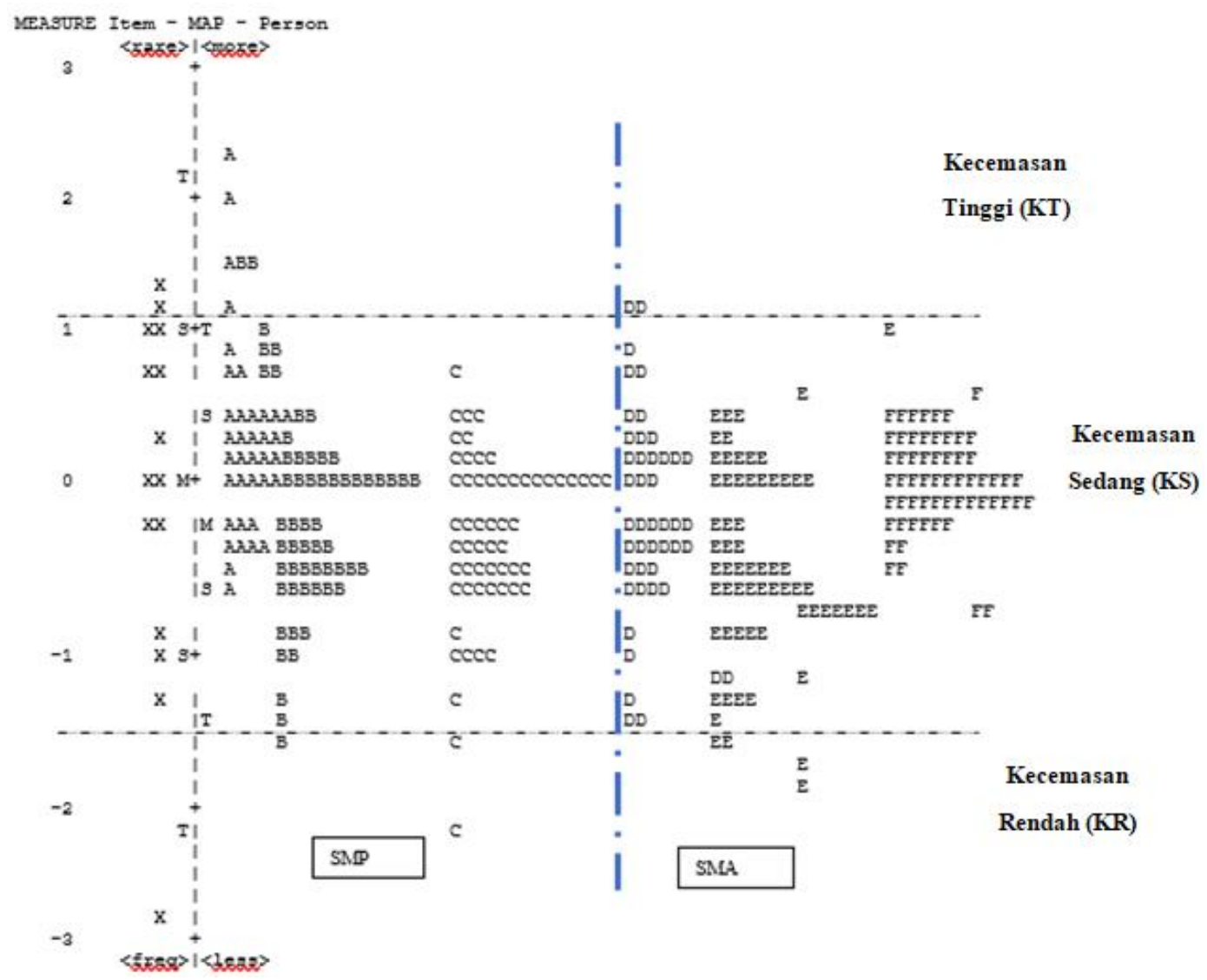

Gambar 2. Variabel Maps Berdasarkan Tingkatan Sekolah

Kecemasan tingkat sedang dialami oleh SMP sebesar 94,11\% dan SMA sebesar 96,4\%. Artinya kecemasan tingkat sedang siswa SMA lebih besar daripada siswa SMP. Sedangkan kecemasan tingkat rendah dialami oleh siswa SMP sebesar 1,96\% dan siswa SMA sebesar 2,3\%. Artinya kecemasan tingkat rendah lebih didominasi oleh siswa SMA daripada siswa SMP. Hasil persentase dihitung dari setiap tingkatan (siswa SMP dan SMA), bukan dari semua total responden. Siswa dengan kecemasan kategori rendah lebih terlihat tanggap dan sangat bersemangat dalam pembelajaran Matematika dibandingkan dengan dua kategori lainnya yaitu kategori kecemasan sedang dan kecemasan tinggi (Wantika \& Nasution, 2019). Selain itu, kecemasan matematis yang dialami siswa SMA disebabkan oleh rasa percaya diri yang rendah, tidak suka terhadap matematika, merasa matematika merupakan pelajaran yang 
tidak menyenangkan, dan kurangnya kemampuan matematis siswa (Supriatna \& Zulkarnaen, 2019).

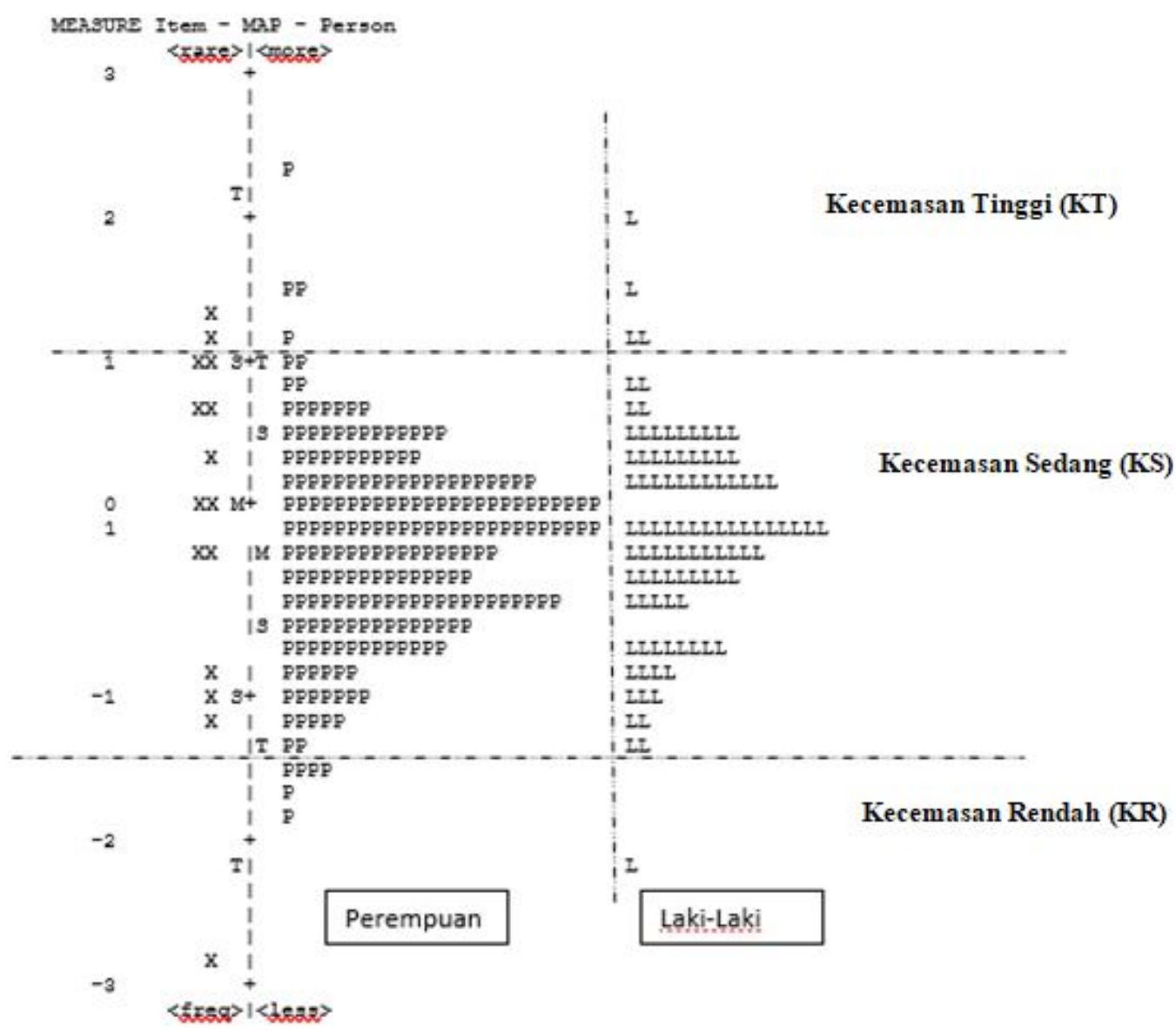

Gambar 3. Variabel Maps Kecemasan Matematika Berdasarkan Jenis Kelamin

Gambar 3 menunjukkan bahwa siswa laki-laki memiliki kecemasan lebih tinggi dibandingkan siswa perempuan. Kecemasan siswa laki-laki sebesar 4\%, sedangkan kecemasan siswa perempuan sebesar 1,8 \%. Hasil persentase dihitung dari setiap total jenis kelamin (siswa SMP dan SMA), bukan dari semua total responden. Hal ini bertolakbelakang dengan hasil penelitian Imro'ah et al. (2019) bahwa siswa perempuan memiliki kecemasan lebih dibandingkan siswa laki-laki. Siswa yang cemas pada saat pembelajaran matematika disebabkan karena siswa cenderung malas belajar matematika.

\section{Kesimpulan}

Berdasarkan hasil analisis yang dilakukan dengan menggunakan WinSteps dike- 
tahui bahwa siswa yang memiliki kecemasan tinggi saat belajar matematika secara online dimasa pandemi covid-19 adalah 3,92\% siswa SMP dan 1,17\% siswa SMA. Kecemasan sedang dialami oleh siswa SMA sebesar 96,4\% dan siswa SMP sebesar 94,11\%. Kecemasan rendah dialami oleh siswa SMA sebesar 2,3\% dan siswa SMP sebesar 1,96\%. Dalam hal gender, siswa laki-laki memiliki tingkat kecemasan belajar matematika sebesar $4 \%$, lebih tinggi daripada siswa perempuan dengan persentase sebesar 1,8\%. Sehingga dapat disimpulkan bahwa pada kategori kecemasan tingkat tinggi, siswa SMP memiliki persentase kecemasan lebih tinggi dibanding siswa SMA. Sedangkan pada kategori kecemasan tingkat sedang dan rendah, siswa SMA memiliki persentase yang lebih tinggi dibandingkan siswa SMP. Hal ini dapat terjadi karena siswa dengan kecemasan tinggi biasanya tidak menyukai matematika dan menganggap matematika adalah pelajaran yang sulit. Salah satu masukan yang dapat dilakukan oleh guru, khususnya pengajar di SMP, sebaiknya lebih ditingkatkan pemberian motivasi pada siswa dalam bentuk penggunaan metode belajar yang menyenangkan sehingga siswa tidak cemas selama pembelajaran matematika

\section{Daftar Pustaka}

Adnan, M. (2020). Online learning amid the COVID-19 pandemic: Students perspectives. Journal of Pedagogical Research, 1(2), 45-51. https:// doi.org/ 10.33902/jpsp.2020261309

Assareh, A., \& Bidokht, M. H. (2011). Barriers to E-teaching and E-learning. Procedia Computer Science, 3, 791-795. https:// doi.org/ 10.1016/ j.procs.2010.12.129

Aydın, D., \& Aytekin, C. (2019). Controlling mathematics anxiety by the views of guidance and psychological counseling candidates. European Journal of Educational Research, 8(2), 421-431. https:/ / doi.org/ 10.12973/ eu-jer.8.2.421

Azis, Y. M., Suharyati, H., \& Susanti, S. (2019). Student ' S Experience of E -Learning , Learning Process and. 03(02), 67-70.

Cheema, J. R., \& Sheridan, K. (2015). Time spent on homework, mathematics anxiety and mathematics achievement: Evidence from a US sample. Issues in Educational Research, 25(3), 246-259. http:/ / search.ebscohost.com/ login.aspx?direct=true\&db=eft\&AN=109114385 \&site=ehost-live

Curran, V., Gustafson, D. L., Simmons, K., Lannon, H., Wang, C., Garmsiri, M., Fleet, L., \& Wetsch, L. (2019). Adult learners' perceptions of self-directed learning and digital technology usage in continuing professional education: An update for 
the digital age. Journal of Adult and Continuing Education, 25(1), 74-93. https:/ / doi.org/ 10.1177/ 1477971419827318

Damary, R., Markova, T., \& Pryadilina, N. (2017). Key Challenges of On-line Education in Multi-cultural Context. Procedia - Social and Behavioral Sciences, 237(June 2016), 83-89. https:/ / doi.org/ 10.1016/ j.sbspro.2017.02.034

Dowker, A., Sarkar, A., \& Looi, C. Y. (2016). Mathematics anxiety: What have we learned in 60 years? Frontiers in Psychology, 7(APR). https:/ / doi.org/ 10.3389/ fpsyg.2016.00508

Hill, F., Mammarella, I. C., Devine, A., Caviola, S., Passolunghi, M. C., \& Szucs, D. (2016). Maths anxiety in primary and secondary school students: Gender differences, developmental changes and anxiety specificity. Learning and Individual Differences, 48, 45-53. https:/ / doi.org/ 10.1016/ j.lindif.2016.02.006

Himmi, N., \& Azni, A. (2017). Hubungan Kesiapan Belajar Dan Kecemasan Matematika Terhadap Hasil Belajar Matematika Siswa SMP. PYTHAGORAS: Jurnal Program Studi Pendidikan Matematika, 6(1), 22-30. https:// doi.org/ 10.33373/ pythagoras.v6i1.619

Imro'ah, S., Winarso, W., \& Baskoro, E. P. (2019). Analisis Gender Terhadap Kecemasan Matematika Dan Self Efficacy Siswa. KALAMATIKA Jurnal Pendidikan Matematika, $4(1)$, 23-36. https:/ / doi.org/ 10.22236/ kalamatika.vol4no1.2019pp23-36

Tiara, K. (2016). Technomedia Journal (TMJ). Penerapan Rinfosheet Sebagai Media Penunjang Pembuatan Laporan Untuk Mahasiswa, 53(9), 1689-1699. https:/ / doi.org/ 10.1017/ CBO9781107415324.004

Mailizar, Almanthari, A., Maulina, S., \& Bruce, S. (2020). Secondary school mathematics teachers' views on e-learning implementation barriers during the COVID-19 pandemic: The case of Indonesia. Eurasia Journal of Mathematics, Science and Technology Education, 16(7). https:/ / doi.org/ 10.29333/ EJMSTE/ 8240

Markova, T., Glazkova, I., \& Zaborova, E. (2017). Quality Issues of Online Distance Learning. Procedia - Social and Behavioral Sciences, 237(June 2016), 685-691. https:/ / doi.org/ 10.1016/ j.sbspro.2017.02.043

Moss, D. (2002). Psychological perspectives: Anxiety disorders: Identification and intervention. Psychological Perspectives: Anxiety Disorders: Identification and Intervention., January. https:// www.researchgate.net/ publication/ 259560188_Psychological_perspec tives_Anxiety_disorders_Identification_and_intervention

Mutlu, Y. (2019). Math anxiety in students with and without math learning difficulties. International Electronic Journal of Elementary Education, 11(5), 471-475. https:/ / doi.org/ 10.26822/ iejee.2019553343 
Ölmez, İ. B., \& Ölmez, S. B. (2019). Validation of the Math Anxiety Scale with the Rasch Measurement Model. Mathematics Education Research Journal, 31(1), 89-106. https:/ / doi.org/ 10.1007/ s13394-018-0244-8

Rahayu, U., Darmayanti, T., Widodo, A., \& Redjeki, S. (2017). The development of CERDAS learning strategy guide for science education students of distance education. Journal of Physics: Conference Series, 812. https:// doi.org/ 10.1088/ 1742-6596/ 755/ 1/ 011001

Sumintono, B. \& Widhiarso, W. (2014). Aplikasi Rasch Model (B. Trim (ed.); Edisi Revi).

Supriatna, A., \& Zulkarnaen, R. (2019). Studi Kasus Tingkat Kecemasan Matematis Siswa SMA. Prosiding Seminar Nasional Matematika Dam Pendidikan Matematika, 730-735.

Ulfiani, R., Nursalam, N., \& M. Ridwan, T. (2015). Pengaruh kecemasan dan kesulitan belajar matematika terhadap hasil belajar matematika pada siswa kelas $\mathrm{x}$ ma negeri 1 watampone kabupaten bone. MaPan: Jurnal Matematika Dan Pembelajaran, $\quad 3(1)$,

86-102. http:/ / journal.uin-alauddin.ac.id/ index.php/ Mapan/ article/ view/ 2752

Wahyudy, H. E. putri. (2019). Penerapan Pendekatan Concrete-Pictorial-Abstract (CPA) dalam Menurunkan Kecemasan Matematis Siswa Sekolah. Simposium Nasional Ilmiah \& Call for Paper Unindra (Simponi)., 11(November), 228-238. https:// doi.org/ 10.30998/ simponi.v0i0.428

Wantika, W., \& Nasution, S. P. (2019). Analisis Kesulitan Belajar dalam Memahami Kecemasan Peserta Didik pada Pembelajaran Matematika. Desimal: Jurnal Matematika, 2(1), 49-57. https:/ / doi.org/ 10.24042/ djm.v2i1.2027

Willse, J. T. (2017). Polytomous rasch models in counseling assessment. Measurement and Evaluation in Counseling and Development, 50(4), 248-255. https:/ / doi.org/ 10.1080/ 07481756.2017.1362656

Zaharah, Kirilova, Galia Ildusocna, \& Windarti, A. (2020). Dampak Wabah Virus Corona Terhadap Kegiatan Belajar Mengajar di Indonesia. Salam: Jurnal Sosial Dan Budaya Syar'i, 7(3), 269-282. https:// doi.org/ 10.15408 / sjsbs.v7i3.15104 